\title{
HYBRIDIZATION BETWEEN NATIVE AND INVASIVE ALIEN PLANTS: AN OVERLOOKED THREAT TO THE BIODIVERSITY OF SRI LANKA
}

\author{
Deepthi Yakandawala $^{1^{*}}$ and Kapila Yakandawala ${ }^{2}$ \\ ${ }^{1}$ Department of Botany, University of Peradeniya, Peradeniya, Sri Lanka \\ ${ }^{2}$ Department of Horticulture \& Landscape Gardening, Faculty of Agriculture \& Plantation Management, \\ Wayamba University of Sri Lanka, Makandura, Gonawila, Sri Lanka \\ Accepted 16 May 2011
}

\begin{abstract}
Conservation of native biological diversity is one of the major challenges of this century. Invasive alien species (IAS) are a part of this challenge because a small but a significant fraction of IAS contribute to the demise of native species. The present paper reviews current literature on the phenomenon of hybridization in plants supporting the evolution of invasiveness, which is identified as a major threat to the extinction of native species. Further, the phenomenon of hybridization is been reviewed on a Sri Lankan context by citing evidence from a preliminary study between the native Nymphaea nouchali and an introduced violet flowered water-lily that has got established in water-bodies of Sri Lanka. This violet flowered water-lily has been incorrectly identified as the native Nymphaea nouchali, the National flower of Sri Lanka ('Nil Manel'). Revealing the flawed identity of the violet flowered Nymphaea, its hybrid origin and the hybridization with the native $N$. nouchali, provides an excellent opportunity for initiating studies on a novel area in hybridization between natives and invasive alien species of plants in Sri Lanka.
\end{abstract}

Key words: biodiversity conservation, Nymphaea, evolution, 'Nil Manel', Invasive Alien Species (IAS)

Biological invasions are considered as serious threats to the biodiversity and presently ranked second only to habitat loss (Gurevitch and Padilla, 2004; Didham et al., 2005; Tiebre et al., 2007). However, according to Chapin et al. (2000), biological invasion may soon surpass habitat loss as the main cause of environmental degradation globally. This ranking has attracted greater attention towards Invasive Alien Species (IAS) in the last decade (Gurevitch and Padilla, 2004; Didham et al., 2005; Tiebre et al., 2007). Invasive Alien Species have the ability to compete with and replace native biota in natural habitats, thereby causing an immense threat to the native biological diversity. They possess special characteristics that enable them to spread fast and aggressively and compete with native flora and fauna, to form large populations that interfere with the ecological balance and the natural development of biotic communities. Generally IAS are identified under different terminologies such as 'exotics', 'aliens', 'nonnatives' 'noxious' 'non-indigenous' or 'weedy' species, based on the approach and emphasis of the study (Colautti and MacIsaac, 2004).

$\overline{\text { *Corresponding author’s email: deepthiy@pdn.ac.lk }}$

\section{Biodiversity in Sri Lanka}

Despite its relatively small land area of $65,610 \mathrm{~km}^{2}$, Sri Lanka harbours over 3,770 flowering plant species of which over a quarter are considered endemic to the island (IUCN Red Data List, 2007). Sri Lanka's varied climate and topography, has resulted in a rich biodiversity and the island is considered as one of the most biologically diverse areas in South Asia. The region including the Western Ghats of India and Sri Lanka together is considered as one of 34 biodiversity hotspots recognized in the world (Mittermeier et al., 2005). These hotspots are areas that harbour an exceptionally high concentration of endemic species, but have already lost more than $75 \%$ of the primary vegetation (IUCN Red Data List, 2007). Of all the hotspots, the Western Ghats and Sri Lanka has the highest human population density (Cincotta et al., 2000). The increase in human population on the island has resulted in the loss of biodiversity, due to anthropogenic factors such as habitat degradation and modification, over-exploitation of species, spread of invasive alien species and pollution (IUCN Red Data List, 2007). 


\section{Invasive alien species and island flora}

According to Elton, (1958) and Donlan et al. (2003), islands have long been considered to be under intense ecological threat from the spread of invasive alien species. Sufficient evidence has emerged that IAS may now be the most significant drivers of population declines and species extinctions in island ecosystems globally (Veitch and Clout, 2002; Donlan et al., 2003). Oceanic island floras are often disharmonic, with representation of families differing from that on the neighbouring mainland (Loope and MuellerDombois, 1989). In this context, introductions of IAS are of particular concern to Sri Lanka. In addition to being an island, several other factors such as smaller size, developing economic status, high levels of species endemism in the southwest of the country, highly threatened status of many endemic species and their habitats, and increased degradation and fragmentation of natural habitats due to development activities are few other factors that make IAS important (Clout, 1995; Marambe et al., 2001).

\section{Introduction of IAS to Sri Lanka}

The introduction of IAS into the country in the past, either by intentional or unintentional anthropogenic dispersal moves, has had a direct impact on the country's economy either as alien pests, or as weeds (Marambe et al., 2001). Intentional introductions include deliberate introductions for use in agriculture, forestry, horticulture, fisheries, aquaculture, landscaping, zoological gardens, pet trade etc. and Sri Lanka has experienced several such incidents in the past. The Royal Botanic Gardens, Peradeniya has played a major role in many plant introductions where some plants, such as Eichhornia crassipes (E. Water Hyacinth, S. Japan-jabara), have become serious invaders (Wijesundara, 2001). Salvinia molesta is another plant introduced to the island in 1939 on scientific interest (Senaratna, 1943). Unintentional introductions include accidental introductions of species through transport, trade, travel, tourism, etc., and the weed, Parthenium hysterophorus is one such alien species (Jayasuriya, 2001). The direct economic consequences of IAS are more prominent in the agricultural sector and irrigation systems, while the indirect impacts include a variety of human concerns relating to health, transportation, recreation and loss of biodiversity. However, in the recent years, more interest has been paid towards the introduction of IAS and their impacts on the local biodiversity.

\section{Current research and future trends}

Many studies locally and globally, have been carried out covering different aspects of IAS, and also analysing and building up models for predicting future consequences.

Invasive alien species have attracted the attention of evolutionary biologists and ecologists because they represent historical examples of dramatic evolutionary and ecological changes. Many of the IAS species that become successful only do so either following an unusually long lag time after initial arrival, and/or after multiple introductions (Tiebre et al., 2007; Ellstrand and Schierenbeck, 2006). Discussions on the population biology of invasives have focused largely on their ecology and the evolutionary consequences of the invasive process. Certain ecological explanations for invasiveness include encountering an unfilled niche (Williamson 1996), increased competitive ability relative to the native biota (Holway, 1999), unavailability of natural enemies (Callaway et al., 2004) or ecological release (Ellstrand and Schierenbeck, 2006).

Perhaps the most frequently documented effects of IAS are their suppression of native populations through predation, competition, parasitism, or disease (Chornesky and Randall, 2003). However, the evolution of invasiveness as an adaptive trait has been less addressed (Ellstrand and Schierenbeck, 2006). Anderson and Stebbins (1954) and Abbott (1992) attribute invasiveness to the phenomenon of hybridization (Ellstrand and Schierenbeck, 2006 and reference there in). Few other evolutionary pathways to invasiveness have already received some attention. For example, weeds have evolved to mimic unrelated crops and have become successful invaders of agro-ecosystems (Barrett, 1983). Likewise, Jain and Martins (1979) witnessed a single gene mutation that is apparently answerable for the appearance of invasiveness in rose clover in California.

Ellstrand and Schierenbeck (2006), analysed the concept of hybridization to build up a possible model for the evolution of invasiveness. According to the model hybridization can, through one or more mechanisms catalyze the evolution of invasiveness. Human dispersal and disturbances together act to accelerate the process and increase the opportunities to take hold the hybrid lineages. However, it should be noted that only a fraction of hybridization events will lead to the evolution of invasiveness. In addition, they propose an evolutionary mechanism that may account for these observations. Hybridization between species or between disparate source populations may serve 
as a stimulus for the evolution of invasiveness. Progeny with a history of hybridization may enjoy one or more potential genetic benefits relative to their progenitors. The observed lag times and multiple introductions that seem a prerequisite for certain species to evolve invasiveness may be a correlate of the time necessary for previously isolated populations to come into contact and for hybridization to occur. Hybridization may result in critical evolutionary changes that create an opportunity for increased invasiveness. Abbott (1992) observed that interspecific hybridization involving non-native plant species has often served as a stimulus for the evolution of entirely new, and sometimes invasive, species. Specifically, Abbott (1992) noted that hybridization involving a non-native species and another (either native or non-native) has led to a numeral new sexually reproducing plant species, which are either stabilized introgressants or allopolyploids. Some of these species have remained localized, but most have spread successfully far beyond their sites of origin.

Tiebre et al. (2007) studying the pattern of hybridization and its evolutionary consequences of the invasive alien knotweeds, Fallopia spp. in Belgium observed a high level of genotypic diversity in the hybrid taxa compared to the parental species confirming the occurrence of interspecific hybridization among the Fallopia taxa in Belgium and the restoration of sexual reproduction by hybridization with the invasive alien Fallopia complex. This high genotypic diversity may increase the potential of the taxa to adapt and differentiate into new environments and contribute to the dramatic invasive success of knotweeds in their adventive range. In the absence of hybridization the interaction between the native and introduced species is essentially a competitive one between species that are similar in many aspects of their ecology and life histories. Assuming a homogeneous environment, without interbreeding, the species with the greater fitness (e.g. better competitor or higher reproductive rate) will dominate at equilibrium (Huxel, 1999).

Sri Lanka has experienced several breakthroughs of invasive alien species time to time. Even though Sri Lanka is blessed with a rich biodiversity, majority of plants used in agriculture, forestry, and ornamental plant industry are not native to the country. However, most of the plants that have been introduced are not invasive; they carry out their intended purpose and therefore benefit humans in multiple ways, causing no apparent problems.
Nevertheless, a small proportion of the introduced plants that escaped from cultivation have become pests of natural areas. Many of such examples come from the ornamental plant industry where plants such as Eichhornia crassipes and Lantana camera have become serious invaders (Amarasinghe, 2001). While at present few other ornamental aquatic plants such as Mayaca fluviatilis, Ludwigia sedoides and Echinodorus spp. have been identified with the potential of invading the wet-zone aquatic ecosystems (Yakandawala and Yakandawala, 2007; Debarawatta and Yakandawala, 2009; Yakandawala and Dissanayake, 2010). Ornamental aquatic plant industry plays a leading role in the introduction of aliens into local water-bodies. Although Sri Lanka harbours a large number of naturally occurring aquatics, there is a demand for certain exotics in the export market and this has resulted in the importation of alien plants into the country, to be propagated and exported. According to statistics of the National Aquaculture Development Authority of Sri Lanka (NAQDA), 180 plants have been listed under ornamental aquatics and 87 are being propagated for exportation. Among them 123 have been identified as exotic species (Yakandawala and Yakandawala, 2007).

\section{A silent invader in local water-bodies: a case study}

Water-lilies have been popular as an ornamental aquatic plant in Sri Lanka from ancient times as they produce striking flowers throughout the year. They are represented in Sri Lanka by the genus Nymphaea L., and its two species, N. nouchali Burm. f. (Fig. 1, A, C, E and $\mathrm{G}$ ) and $N$. pubescens Willd. (Dassanayake, 1996). In addition to these native water-lilies, few ornamental species have been introduced in the past where one species, a violet flowered Nymphaea (Fig. 1, B, D, F and H) has become naturalized. This plant has been incorrectly identified as $N$. nouchali by several authors (Kottegoda, 1994; Sumithraarachchi et al., 1995; Samarakoon and Peiris, 2005; Mohan Maruga Raja, 2010). A preliminary investigation was initiated by the authors to identify and estimate the extent of the spread of this alien water-lily. Over 120 water-bodies covering all three major climatic zones of the island; Wet, Intermediate and Dry zones encompassing large, medium and small tanks, pools and ditches, were examined. The study revealed the abundant occurrence of the violet flowered Nymphaea species in $40 \%$ of the water-bodies (Fig. 2). The violet flowered 

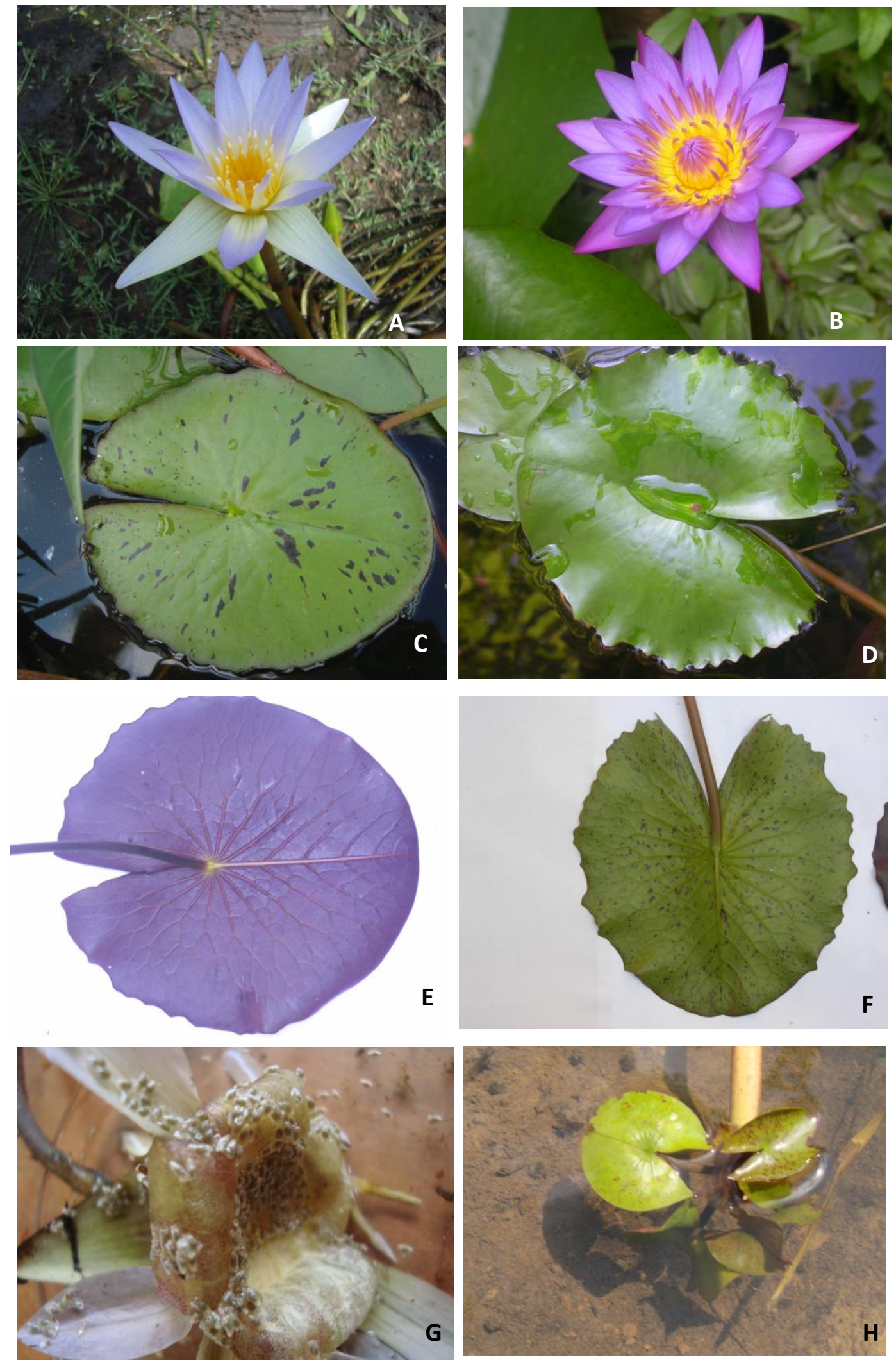

Figure 1. Nymphaea nouchali (A) Flower, (C) Leaf upper surface, (E) Leaf under surface, (G) Fruit with seeds. Violet flowered Nymphaea species (B) Flower, (D) Leaf upper surface, (F) Leaf under surface, (H) 15 -20 days old plantlets, still attached to the parent plant. 


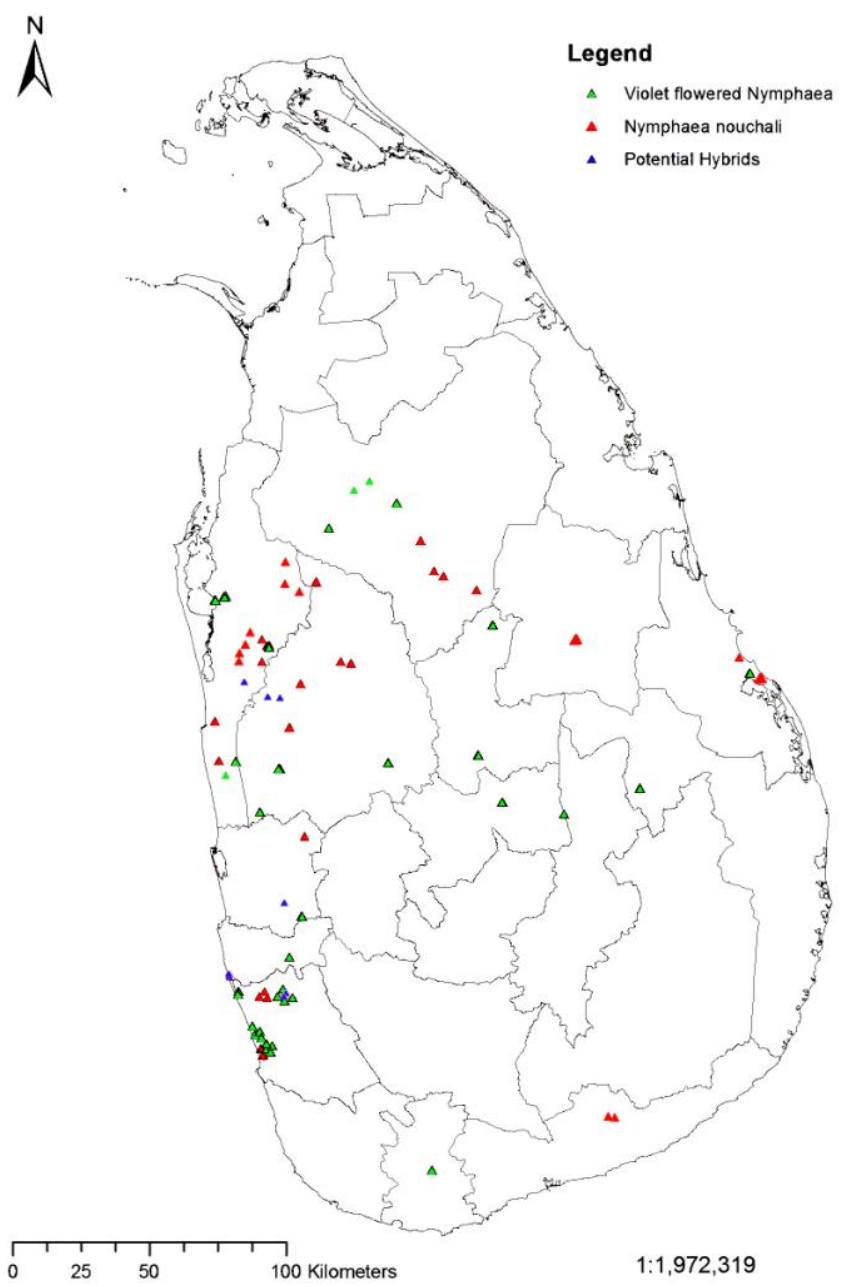

Figure 2. Map of Sri Lanka showing the collection sites of different Nymphaea species included in the study.

Nymphaea species has not only invaded the natural habitats of $N$. nouchali, but also has extended its territory into larger tanks inhabited by other aquatic macrophytes. The large floating leaves cut down a fair percentage of the light that penetrates into the water. Pure $N$. nouchali populations were encountered in $45 \%$ of the water-bodies (periphery of medium sized pools and ditches). The violet flowered Nymphaea is thought to have been introduced into the country as an ornamental aquatic long time ago, and has got established in local water-bodies. Studies on the nomenclature of the violet flowered Nymphaea is currently in progress (manuscript in preparation). Based on the studies conducted by the authors, the plant has been identified as a hybrid, with one parent being N. micrantha Gill.
\& Perr. The other likely parent is either $N$. capensis Thunb., or N. caerulea Savigny. Its link to $N$. micrantha is due to the viviparous nature, as proliferating leaves are recorded only in $N$. micrantha that is native to Senegal, West Africa (Slocum, 1996; Wiersema, 1997). Crossing of the vivipary with other desirable factors is the ease in which these hybrids could be propagated, which is perpetuate through the young plantlets that grow upon the leaves of the parent plant.

Over thirty popular tropical day blooming viviparous cultivars have been developed with $N$. micrantha as a parent and are popular in aquatic landscapes (Knotts, 2003). Nymphaea 'Tina' and Nymphaea 'Panama Pacific' are two such cultivars that show features similar to the Nymphaea sp. with violet flowers found in Sri 
Lanka. The latter is a viviparous variety that is said to be one of the hardiest of the tropicals and also occurs in India (http://botany.csdl.tamu.edu /FLORA/imaxxnym.htm; and http://www. flowersofindia.net/index. html). The ability of this violet flowered Nymphaea to conquer the water-bodies of the island as a silent invader could be attributed to its hybrid nature. It is also possible that several introductions were also made into the country at different times, where the populations had the opportunity to mix and initiate the invasiveness, and the most suitable violet flowered hybrid getting established extending its territory. Meanwhile the ornamental value of it aided by the human involvement could have played a role in its spread. Due to the incorrect identification of the alien violet flowered Nymphaea species as $N$. nouchali ('Nil manel'), the national flower of Sri Lanka, at present this hybrid plays a prominent role in social, cultural and religious events. It does not produce viable seeds but reproduces by vivipary, which is an effective method of propagation and dispersal (Fig. 1, H). Virtually almost all the mature leaves are capable of producing a plantlet at the junction where the petiole meets the leaf lamina.

The present study also revealed populations of Nymphaea with intermediate characters (15\%), indicating hybridization of the native $N$. nouchali with the alien violet flowered hybrid Nymphaea (Fig. 3, Hybrid I- A, C, E, G and Hybrid II- B, D, F, H and Table 1). The hybridization of invasive aliens with native flora is currently identified as a major threat that could lead to the extinction of the native flora (Levin et al., 1996; Wolf et al., 2001; D'Antonio and Meyerson, 2002). Wolf et al. (2001) investigated a number of ecological parameters likely to affect the extinction risk, through an individual based model that simulate the life cycle of two hybridizing annual plant species. It has revealed that, hybridization increased either the probability or the rapidity of extinction for one or both species studied. A study on two cordgrass species, a native and an invader, has revealed that due to the substantially higher male fitness of the invader, native cordgrass could be in danger of extinction (Anttila, 1998). Further, the same study revealed that the hybrids occupying the intertidal range are more similar to the invader than to the native parent, whose introgression would lead to habitat loss for shore birds and marine life as well to genetic pollution of native California cordgrass. Hybridization appears to contribute to species decline in two general ways (Ellstrand and Elam, 1993; Levin et al., 1996; Ellstrand et al., 1999). If the hybrids display reduced fitness relative to either parental species (i.e., outbreeding depression), the growth rate of the numerically inferior taxon may decline below that required for replacement (i.e., demographic swamping). Alternatively, if hybrids are fertile and exhibit little or no decrease in fitness, they may displace pure conspecifics of one or both hybridizing taxa (i.e., genetic assimilation). In addition, the decline of hybridizing species can often be attributed to the synergistic action of demographic swamping and genetic assimilation, and it may be difficult to distinguish between the two species (Wolf et al., 2001).

Species that are most at risk to hybridization are out-crossing plants (Huxel, 1999). Further, displacement of native taxa by non-native taxa can occur very rapidly. Given the number of cryptic species and the high rates of humanmediated species introductions, extinctions may result from hybridization alone. Results have also indicated that introgression enhances displacement at low immigration rates, but impedes it when the native species has a large selective advantage and at higher rates of immigration. However, because of increased frequency of hybrids with introgression, the native is still heavily impacted and its likelihood of extinction is greatly increased. Nevertheless, it should also be noted that invasive alien species pose a hybridization threat proportional to their advantage over natives in the gene flow. Sympatry, interfertility, and rarity of natives are the characteristics previously seen to afford invaders a gene flow advantage (Ellstrand, 1992).

Island biota receives special attention in discussions as hybridization with IAS may be a significant threat to rare species on islands, thereby diluting the native gene pool to the point of extinction in a hybrid swarm (Reaser et al., 2007). Examples of island plants threatened by hybridization with invasive plants include the common butterwort (Pinguicula vulgaris), which is locally rare in the British Isles, and Canary madrona (Arbutus canariensis) and Hawaiian ebony (Gossypium tomentosum), which are endemic to the Canary and Hawaiian Islands, respectively (Levin et al. 1996). There are no previous records on Sri Lankan invasives and, studies conducted in Sri Lanka have mainly focused on the impacts, control and management of IAS (Jayarathne and Ranwala, 2010). The present review is the first report on the interbreeding of a potentially invading plant species with a native species. 

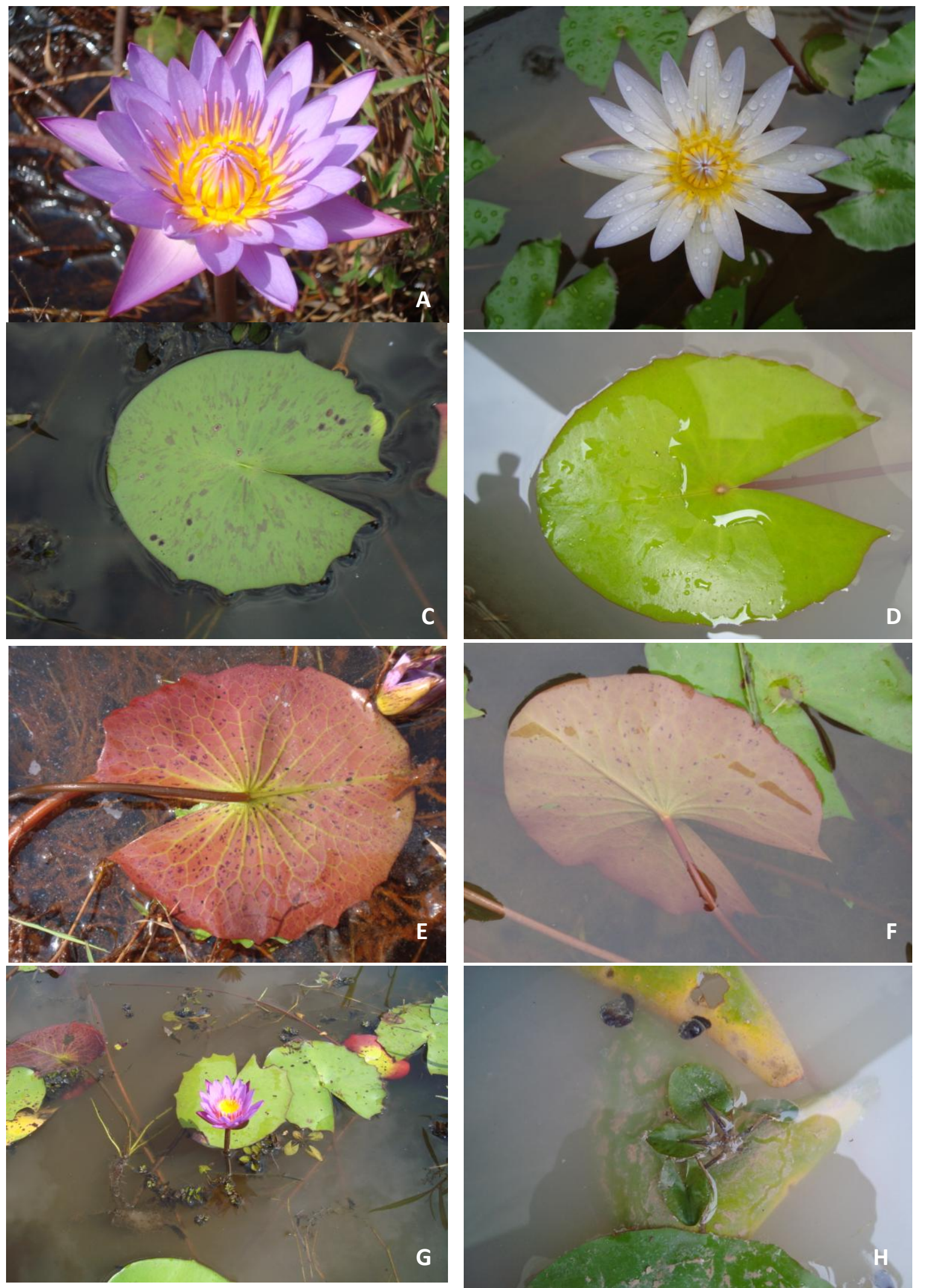

Figure 3. Hybrids of Nymphaea; Hybrid I (A) Flower, (C) Leaf upper surface, (E) Leaf under surface, (G) Vivipary - note plantlets. Hybrid II (B) Flower; (D) Leaf upper surface, (F) Leaf lower surface, (H) Initiation of leaf vivipary. 
Table 1. Comparison of morphological characters of parents and hybrids of Nymphaea.

\begin{tabular}{|c|c|c|c|c|}
\hline $\begin{array}{l}\text { Morphological } \\
\text { Character }\end{array}$ & $\begin{array}{l}\text { N. nouchali } \\
\text { (Native species) }\end{array}$ & $\begin{array}{l}\text { Exotic violet } \\
\text { flowered Nymphaea } \\
\text { species }\end{array}$ & $\begin{array}{l}\text { Hybrids of exo } \\
\text { flowered } N y m_{I} \\
\text { N. nouchali }\end{array}$ & $\begin{array}{l}\text { ic violet } \\
\text { haea and native }\end{array}$ \\
\hline Flower colour & pale blue/pink/white* & violet & $\begin{array}{l}\text { Hybrid I } \\
\text { violet }\end{array}$ & $\begin{array}{l}\text { Hybrid II } \\
\text { pale blue }\end{array}$ \\
\hline Stamen number & $12-50$ & $>120$ & $>100$ & $40-48$ \\
\hline Stamen colour & faint yellow & bright yellow & bright yellow & bright yellow \\
\hline Petal number & $10-15$ & $25-27$ & $25-27$ & $12-15$ \\
\hline Leaf upper surface & $\begin{array}{l}\text { green with occasional } \\
\text { brown blotches }\end{array}$ & glossy dark green & $\begin{array}{l}\text { green with } \\
\text { occasional } \\
\text { brown } \\
\text { blotches }\end{array}$ & glossy green \\
\hline Leaf lower surface & $\begin{array}{l}\text { dark to light purplish } \\
\text { green lower surface }\end{array}$ & $\begin{array}{l}\text { light green with purple } \\
\text { streaks }\end{array}$ & $\begin{array}{l}\text { reddish purple } \\
\text { with purple } \\
\text { streaks }\end{array}$ & $\begin{array}{l}\text { reddish purple } \\
\text { with purple } \\
\text { streaks }\end{array}$ \\
\hline Vivipary & absent & present & present & present \\
\hline
\end{tabular}

Identification of invasives, a pre-requisite

Identification of these hybrid taxa from the parent taxa is important as eradication of such taxa in the early stage is an achievable goal (Castillo, 2010). Studies highlight the identification of the hybrid taxa as the base for studying the invasion ecology of congeneric species. Further, the basis for such a study lies in the identification of the parent taxa (Tiebre et al., 2007). The present incorrect identification of the violet flowered Nymphaea species as native $N$. nouchali is a classic example where the former species is treated as a native as well as the national flower of Sri Lanka, overlooking the invasiveness. Similar example are hybrids of cordgrass, where genetically diverse, introgressive hybrids (Ayres et al., 1999; Anttila et al., 2000) between Spartina foliosa Trin. (native California cordgrass) and S. alterniflora Loisel (alien - Atlantic smooth cordgrass) originated in the tidal salt marshes of San Francisco Bay following the introduction of Atlantic smooth cordgrass, into the range of the native California cordgrass (Ayres et al., 1999; Faber, 2000). Early workers (Callaway and Josselyn, 1992; Daehler and Strong, 1994) assumed that the cordgrass invader was Atlantic smooth cordgrass. Nevertheless, later work using molecular markers suggested that the plants invading new sites were hybrids and that pure Atlantic smooth cordgrass plants were common only in sites where they were initially planted (Ayres et al., 1999; Ayres, et al., 2008). Therefore, identification of newly formed hybrids using morphological characters alone may lead to an underestimation of the true extent of species diversity (Petit, 2004; Lopez et al., 2005; Mallet, 2005). Combining morphological and molecular data would be an efficient tool for differentiating taxa within complex populations (Persson and Gustavsson, 2001; Cattell and Karl, 2004).

Revealing the flawed identity of the Nymphaea with violet flowers, its hybrid origin and the hybridization with native $N$. nouchali, will open up new avenues in research in invasions of aliens to Sri Lanka. These findings provide an excellent opportunity for initiating studies locally on this novel area of hybridization between natives and invasive alien species. Further, this could be extended to analyze the genetic and evolutionary consequences of hybridization, an overlooked threat to the biodiversity of Sri Lanka.

\section{ACKNOWLEDGEMENTS}

Authors thank Professors D.P.S.T.G. Attanayake and N.E.M. Jayasekara for constructive comments, Mr. Indika Peabotuwage for field assistance and Dr. Jagath Gunatilleke for helping with mapping.

\section{REFERENCES}

Abbott, R. J. (1992). Plant invasions, interspecific hybridization and the evolution of 
new plant taxa. Trends in Ecology and Evolution 7: 401-405.

Amarasinghe, L. (2001). Some invasive flora in agricultural habitats in Sri Lanka. Sri Lankan Biodiversity Review 1: 31-42.

Anderson, E. and Stebbins, G. L. (1954). Hybridization as an evolutionary stimulus. Evolution 8: $378-388$.

Anttila, C. K., Daehler, C. C., Rank, N. E. and Strong, D. R. (1998). Greater male fitness of a rare invader (Spartina alterniflora, Poaceae) threatens a common native (Spartina foliosa) with hybridization. American Journal of Botany 85 (11): 1597-1601.

Anttila, C. K., King, A. R., Ferris, C., Ayres, D. R. and Strong, D. R. (2000). Reciprocal hybrid formation of Spartina in San Francisco Bay. Molecular Ecology 9: 765-771.

Ayres, D. R., Garcia-Rossi, D., Davis, H. G. and Strong, D. R. (1999). Extent and degree of hybridization between exotic (Spartina alterniflora) and native ( $S$. foliosa) cordgrass (Poaceae) in California, USA determined by random amplified polymorphic DNA (RAPDs). Molecular Ecology 8: 1179-1186.

Ayres, D. R., Zaremba, K., Sloop C. M., and Strong, D. R. (2008). Sexual reproduction of cordgrass hybrids (Spartina foliosa $\mathrm{x}$ alterniflora) invading tidal marshes in San Francisco Bay. Diversity and Distributions 14: 187-195.

Barrett, S. C. H. (1983). Crop mimicry in weeds. Economic Botany 37: 255-282.

Callaway, R. M., Thelen, G. C., Rodriguez, A., Holben, W. E. (2004). Release from inhibitory soil biota in Europe may promote exotic plant invasion in North America. Nature 427: 731733.

Callaway, J. C. and Josselyn, M. N. (1992). The introduction and spread of smooth cordgrass (Spartina alterniflora) in South San Francisco Bay. Estuaries 15: 218-226.

Castillo, J. M., Ayres, D. R., Leira-Doce, P., Bailey, J., Blum, M., Strong, D. R., Luque, T. and Figueroa, E. (2010). The production of hybrids with high ecological amplitude between exotic Spartina densiflora and native $S$. maritime in the Iberian Peninsula. Diversity and Distributions 16 (4): 547-558.

Cattell, M. V. and Karl, S. A. (2004). Genetics and morphology in a Borrichia frutescens and $B$. arborescens (Asteraceae) hybrid zone. American Journal of Botany 91: 1757-1766.

Chapin, F. S., Zavaleta, E. S., Viner, V. T., Naylor, R. L., Vitousek, P. M., Sala, O. E., Reynolds, H. L., Hooper, D. U., Mack, R., Diaz, S. E., Hobbie, S. E. and Lavorel, S. (2000). Consequences of changing biodiversity. Nature 405: $234-242$.

Chornesky, E. A. and Randall, J. M. (2003). The threat of invasive alien species to biological diversity: setting a future course. Annals of the Missouri Botanical Garden 90 (1): 67-76.

Cincotta, R. P., Wisnewski, J. and Engelman, R. (2000). Human population in the biodiversity hotspots. Nature 404: 990-992.

Clout, M. (1995). Introduced species: the greatest threat to global biodiversity? Species $\mathbf{2 4}$ : 34-36.

Colautti, R. I. and MacIsaac, H. J. (2004). A neutral terminology to define 'invasive' species. Diversity and Distributions 10 (2): 135-141.

D’Antonio, C. and Meyerson, L. A. (2002). Exotic plant species as problems and solutions in ecological restoration: A synthesis. Restoration Ecology 10 (4): 703-713.

Daehler, C. C. and Strong, D. R. (1994). Variable reproductive output among clones of Spartina alterniflora (Poaceae) invading San Francisco Bay, California: the influence of herbivory, pollination, and establishment site. American Journal of Botany 81: 307-313.

Dassanayake, M. D. (1996). Nymphaeaceae. In: M. D. Dassanayake, and W. D. Clayton (Eds.), A Revised Handbook to the Flora of Ceylon 10. Oxford \& IBH Publishing Co. Pvt., Ltd. New Delhi. Pp. 289-292.

Debarawatta, R. D. N. and Yakandawala, K. (2009). An alien ornamental aquatic Ludwigia sedioides L., a threat to Sri Lankan water bodies? Proceedings of the $9^{\text {th }}$ Agricultural Research Symposium, Wayamba University of Sri Lanka. Pp. 381-385. 
Didham, R. K., Tylianakis, J. M., Hutchison, M. A., Ewers, R. M. and Gemmell. N. J. (2005). Are invasive species the drivers of ecological change? Trends in Ecology and Evolution 20: $470-474$.

Donlan, C. J, Tershy, B. R., Cambell, K. and Cruz, F. (2003). Research for requiems: The need for more collaborative action in eradication of invasive species. Conservation Biology 17: 1850-1851.

Ellstrand, N. C. and Schierenbeck, K. A. (2006). Hybridization as a stimulus for the evolution of invasiveness in plants? Euphytica 148: 35-46.

Ellstrand, N. C. (1992). Gene flow by pollen: implications for plant conservation genetics. Oikos 63: 77-86.

Ellstrand, N. C. and Elam, D. R. (1993). Population genetic consequences of small population size: Implications for plant conservation. Annual Review of Ecology and Systematics 24: 217-242.

Ellstrand, N. C., Prentice, H. C. and Hancock, J. F. (1999). Gene flow and introgression from domesticated plants into their wild relatives. Annual Review of Ecology and Systematics 30: 539-563.

Elton, C.S. (1958). The ecology of invasions by animals and plants. Metheum, London, UK.

Faber, P. (2000). Good intensions gone away. Why would anyone bring an alien codgrass to San Francisco Bay? Coast Ocean 16: 14-17.

Flowers of India http://www.flowersofindia.net /index.html (Accessed on 20th November 2010)

Gurevitch, J. and Padilla, D. (2004). Are invasive species a major cause of extinctions? Trends in Ecology and Evolution 19: 470-474.

Holway, D. A. (1999). Competitive mechanisms underlying the displacement of native ants by the invasive Argentine ant. Ecology 80: 238-251.

Huxel, G. R. (1999). Rapid displacement of native species by invasive species: effects of hybridization. Biological Conservation 89: 143152.

IUCN Red Data List (2007). The 2007 Red List of Threatened Fauna and Flora of Sri Lanka. IUCN Sri Lanka and The Ministry of
Environment and Natural Resources, Colombo, Sri Lanka. xiii+148 Pp.

Jain, S. K. and Martins, P. S. (1979). Ecological genetics of the colonizing ability of rose clover (Trifolium hirtum All.). American Journal of Botany 66: 361-366.

Jayarathne, B. and Ranwala, S. (2010). Research on invasive alien plants in Sri Lanka: An analysis of past work. In: B. Marambe, P. Silva, S. Wijesundara and N. Atapattu (Eds.). Invasive Alien Species Strengthening capacity to control introduction and spread in Sri Lanka, Biodiversity Secretariat of the Ministry of Environment, Sri Lanka. Pp. 179-184.

Jayasuriya, A. H. M. (2001). New invasive weed in Sri Lanka: Parthenium hysterophorus L. (Asteraceae). In: H. P. M. Gunasena (Ed.). Silver Jubilee Lecture Series. No. 1. Postgraduate Institute of Agriculture, University of Peradeniya, Sri Lanka. Pp. 14.

Knotts, K. (2003). Viviparous Water-lilies. www.victoria-adventure.org. (Accessed on $18^{\text {th }}$ November 2010).

Kottegoda, S. R. (1994). Flowers of Sri Lanka. The Royal Asiatic Society of Sri Lanka. P. 247.

Levin, D. A., Francisco-Ortega, J. K. and Jansen, R. K. (1996). Hybridization and the extinction of rare plant species. Conservation Biology 10:1016.

Loope, L. L. and Mueller-Dombois, D. (1989). Characteristics of invaded islands, with special reference to Hawaii. In: J. A. Drake, H. A. Mooney, F. di Castri, R. H. Groves, F. J. Kruger, M. Rejmanek and M. Williamson (Eds.). Biological Invasions: A Global Perspective, Scientific Committee on Problems of the Environment (SCOPE) 37. John Wiley and Sons: New York, NY, USA. Pp. 257-280.

Lopez, M. G., Wulff, A. F., Poggio, L. and Xifreda, C. C. (2005). Chromosome numbers and meiotic studies in the species of Senecio (Asteraceae) from Argentina. Botanical Journal of the Linnaean Society 148: 465-474.

Mallet, J. (2005). Hybridization as an invasion of the genome. Trends in Ecology and Evolution 20: $229-237$.

Marambe, B., Bambaradeniya, C., Pushpa Kumara, D. K. and Pallewatta, N. (2001). 
Human dimensions of invasive alien species in Sri Lanka. In: J.A. McNeely (Ed.). The Great Reshuffling; Human Dimensions of Invasive Alien Species, IUCN, Gland, Switzerland and Cambridge, UK. Pp. 135-142.

Mittermeier, R. A., Gil, P. R., Hoffman, M., Pilgrim, J., Brooks, T., Mittermeier, C. G., Lamoreux, J. and da Fonseca, G. A. B. (2005). Hotspots revisited: Earth's biologically richest and most threatened terrestrial ecoregions. Conservation International, Washington D.C., USA.

Maruga Raja, Mohan M. K., Sethiya, Neeraj Kumar and Mishra, S. H. (2010). A comprehensive review on Nymphaea stellata: A traditionally used bitter. Journal of Advanced Pharmaceutical Technology and Research 1 (3): 311-319.

Persson, H. A. and Gustavsson, B. A. (2001). The extent of clonality and genetic diversity in lingonberry (Vaccinium vitis-idaea L.) revealed by RAPDs and leaf-shape analysis. Molecular Ecology 10: 1385-1397.

Petit, R. J. (2004). Biological invasions at the gene level. Diversity and Distributions 10: 159 165.

Reaser, J. K., Meyerson, L. A., Cronk, Q., De Poorter, M., Eldrege, L. G., Green, E., Kairo, M., Latasi, P., Mack, R. N., Mauremootoo, J., O'dowd, D., Orapa, W., Sastroutomo, S., Saunders, A., Shine, C., Thrainsson, S. and Vaiutu, L. (2007). Ecological and socioeconomic impacts of invasive alien species in island ecosystems. Environmental Conservation 34 (2): 1-14.

Samarakoon, U. C. and Peiris, S. E. (2005). Control of circadian rhythm regulated nyctinastic movement in water lily (Nymphaea stellata) flowers. Journal of Horticultural Science and Biotechnology 80 (2): 167-170.

Senaratna, J. E. (1943). Salvinia auriculata Aulb., a recently introduced free floating weed. Tropical Agriculturist XCIX: 146-149.

Slocum, P. D., Robinson, P. and Perry, F. (1996). Water Gardening: Water Lilies and Lotuses. Timber Press, Inc.

Sumithraarachchi, D. B., Ratnayake, H. D., Ekanayake, S. P. (1995). Beautiful Wild flowers of Sri Lanka. Royal Botanical Gardens,
Peradeniya. Pp.154.

Tiebre, Marie-S., Bizoux, Jean-P., Hardy, O. J., Bailey J. P. and Mahy, G. (2007). Hybridization and morphogenetic variation in the invasive alien Fallopia (Polygonaceae) complex in Belgium. American Journal of Botany 94 (11):1900-1910.

Vascular plant Image library http://botany.csdl. tamu.edu/FLORA/imaxxnym.htm (Accessed on $20^{\text {th }}$ November 2010)

Veitch, C. R. and Clout, M. N. (2002). Turning the Tide: the Eradication of Invasive Species. Proceedings of the International conference on the eradication of island invasives. IUCN Species Specialist Group. Gland, Switzerland and Cambridge, UK.

Wiersema, J. H., and Hellquist, C. B. (1997). Nymphaeaceae. In: N. T. Moran, and editorial committee (Eds.), Flora North America North of Mexico 3. Oxford University Press, New York.

Wijesundara, Siril (2001). Potential invasive plants in Sri Lanka. Sri Lankan Biodiversity Review 1: 73-78.

Williamson, M. (1996). Biological invasions. Chapman \& Hall, London, UK.

Wolf, D. E., Takebayashi, N. and Rieseberg, L. H. (2001). Predicting the risk of extinction through hybridization. Conservation Biology 15 (4): 1039-1053.

Yakandawala, D. and Yakandawala, K. (2007). Ornamental aquatics: potential weeds in aquatic ecosystems. In: B. Marambe, U. R. Sangakkara, W. A. J. M. Costa and A. S. K. Abeysekara (Eds.), Proceedings of the $21^{\text {st }}$ Asian Pacific Weed Science Society Conference, Colombo, Sri Lanka. Pp. 222-225.

Yakandawala, K. and Dissanayake, D. M. G. S. (2010). Mayaca fluviatilis Aubl. : An ornamental aquatic with invasive potential in Sri Lanka. Hydrobiologia 656 (1): 199-204. 